\section{PENELITIAN PENGARUH PENAMBAHAN KOMPON PVC PADA KOMPON KARET UNTUK SOL}

Oleh

\section{KELOMPOK PENELITI PROSES BARANG KARET */}

\section{ABSTRACT}

PVC, is a polymer of vinyl chloride, is added to rubber as reinforcing agent will improve the hardness, modulus and tensile strength of rubber products as observed in this experiments.

By adding 40 parts of PVC compound, the highest value of tensile strength and hardness of the products are 94,0471 $\mathrm{kg} / \mathrm{cm}^{2}$ for tensile strength and 54,6666 shore A for hardness.

\section{PENDAHULUAN}

Kompon karet untuk Sol merupakan hasil pencampuran karet dengan bahan-bahan pembantu yang prosesnya disebut pembuatan komjon (compounding).

Kompon PVC atau bahan pembantu ini dimaksudkan untuk memperbaiki sifat-sifat karet terutama sifat-sifat fisikanya.

PVC merupakan polymer dari vinyl khloride yang jika ditambahkan pada kompon karet alam merupakan reinforcing agent, yang akan dapat memperbaiki kekerasan, modulus dan tensile strength dari produk akhirnya (7).

Kompon ini digunakan untuk pembuatan barang-barang seperti : slang, belting khususnya foot belting, kabel dan sol sepatu (7).

Disini karet berfungsi sebagai plasticizer PVC dan PVC sebagai reinforcing agent untuk karet, PVC yang digunakan berkisar antara 10 - 40 bagian (7).

Untuk mengetahui sampai seberapa banyak PVC yang dapat ditambahkan pada kompon karet sehingga memberikan sifatsifat fisika yang baik, maka perlu diadakan penelitian pengaruh penambahan kompon PVC pada kompon karet untuk sol.

*/ 1. Ir. Titien Sayekti, 2. Ir. Any Setyaningsih, 3. HJ. Supardal BSc, 4. Abuchori BSc, 5. Asrilah BSc, 6. Sagiman, 7. Sri Brotoningsih.

\section{MATERI DAN METODA}

Pada percobaan ini mula-mula membuat dulu kompon PVC.

Komposisi bahan untuk kompon PVC :

$\begin{array}{lr}\text { PVC } & 100 \text { bagian } \\ \text { DOP } & 30 \text { bagian } \\ \text { White Oil } & 5 \text { bagian } \\ \text { Ba Cd Zn } & 1 \text { bagian } \\ \text { Asam stearat } & 1 \text { bagian }\end{array}$

Kemudian membuat kompon karet alam dengan variasi kompon PVC sebagai berikut :

$\begin{array}{lr}\begin{array}{l}\text { Crepe } \\ \text { Whiting (CaCo3) } \\ \text { Kompon PVC }\end{array} & \begin{array}{r}100 \text { bagian } \\ \text { bervarian } \\ \text { kompon PVC. }\end{array} \\ \text { Zn O } & \begin{array}{r}10 \text { bagian } \\ \text { Asam stearat }\end{array} \\ \begin{array}{l}0,5 \text { bagian } \\ \text { Napthenic Oil }\end{array} & 2 \text { bagian } \\ \text { Paraffin Wax } & 0,5 \text { bagian } \\ \text { Ti O2 } & 10 \text { bagian } \\ \text { P.B.N. } & 1 \text { bagian } \\ \text { M.B.T. } & 0,4 \text { bagian } \\ \text { M.B.T.S. } & 0,4 \text { bagian } \\ \text { T.M.T. } & 0,2 \text { bagian } \\ \text { Sulfur } & 2 \text { bagian }\end{array}$

Kompon diatas kemudian dipres dengan pres hidraulik (hydraulic press) pada suhu $170^{\circ} \mathrm{C}$, tekanan $14,7 \mathrm{~N} / \mathrm{mm}^{2}$ waktu 12 menit dan diuji sifat-sifat fisikanya sesuai yang ditetapkan dalam SII No. 10944 Sepatu kanvas untuk umum.

Data hasil pengujian sifat-sifat fisika dianalisa secara statistik dengan metoda CRD.

* 1. Ir. Titien Sayekti, 2. Ir. Any Setyaningsih, 3. HJ. Supardal BSc, 4. Abuchori BSc, 5. Asrilah BSc, 6. Sagiman, 7. Sri Brotoningsih. 


\section{HASIL PENELITIAN DAN PEMBAHASAN}

1. Hasil Penelitian :

Tabel 1. Hasil pengujian fisika

\begin{tabular}{|c|c|c|c|c|c|c|c|}
\hline No. & $\begin{array}{c}\text { Macam } \\
\text { uji } \\
\text { Kompon }\end{array}$ & Satuan & $A(10)$ & $B(20)$ & $c(30)$ & $D(40)$ & Kontrol \\
\hline 1. & $\begin{array}{l}\text { Tegangan } \\
\text { putus }\end{array}$ & $\mathrm{N} / \mathrm{mm}^{2}$ & 6,2539 & 6,3197 & 7,9290 & 9,2260 & 3,8066 \\
\hline 2. & $\begin{array}{l}\text { Perpan- } \\
\text { jangan } \\
\text { putus }\end{array}$ & $\%$ & 113,3333 & 973,3333 & 967,3333 & 929,33331 & 1074,6666 \\
\hline 3. & $\begin{array}{l}\text { Ketahan- } \\
\text { an sobek }\end{array}$ & $\mathrm{N} / \mathrm{mm}^{2}$ & 1,5070 & 1,4862 & 1,4475 & 1,3171 & 1,8452 \\
\hline 4. & $\begin{array}{l}\text { Kekeras- } \\
\text { an }\end{array}$ & Shore A & 49,6666 & 50,6666 & 53,0000 & 54,6666 & 45,6666 \\
\hline 5. & $\begin{array}{l}\text { Perpan- } \\
\text { jangan te } \\
\text { tap } 100 \%\end{array}$ & - & 1,4000 & 0,9333 & 1,3333 & 1,4000 & 1,1333 \\
\hline 6. & $\begin{array}{l}\text { Bobot } \\
\text { Jenis }\end{array}$ & $\mathrm{g} / \mathrm{cm}^{2}$ & 1,3616 & 1,2095 & 1,3002 & 1,2617 & 1,2238 \\
\hline 7. & $\begin{array}{l}\text { Ketahan- } \\
\text { an kikis }\end{array}$ & $\mathrm{mm}^{3} / \mathrm{kgm}$ & 3,3767 & 3,8081 & 5,5286 & 3,5166 & 4,1971 \\
\hline 8. & $\begin{array}{l}\text { Ketahan- } \\
\text { an retak }\end{array}$ & - & tidak & tidak & tidak & tidak & tidak \\
\hline & $\begin{array}{l}\text { lentur } \\
150 \mathrm{kes}\end{array}$ & & retak & retak & retak & retak & retak \\
\hline
\end{tabular}

2. Pembahasan :

Dari hasil pengujian fisika ternyata dengan bertambahnya kompon PVC akan menaikkan tegangan putus dan kekerasan.

Hal ini dikarenakan kompon PVC mempunyai fungsi sebagai reinforcing agent, hal tersebut terlihat dari hasil uji statistik dengan taraf kepercayaan 95\% maupun $99 \%$, sedangkan perpanjangan putus, ketahanan sobek, bobot jenis, ketahanan kikis dan perpanjangan tetap, dari perhitungan statistik dengan LSD $5 \%$ maupun $1 \%$ tidak ada beda nyata.
Tabel 2. Perhitungan statistik dengan metoda CRD untuk uji tegangan putus

\begin{tabular}{c|c|c|c|c|c}
\multirow{2}{*}{$\begin{array}{c}\text { Perla- } \\
\text { kuan }\end{array}$} & \multicolumn{3}{|c|}{ Ulangan } & \multirow{2}{*}{ Total } & $\begin{array}{c}\text { Rata- } \\
\text { rata }\end{array}$ \\
\cline { 2 - 6 } & 1 & 2 & 3 & & \\
\hline A & 6,0444 & 6,2014 & 6,5187 & 18,7645 & 6,2548 \\
B & 6,0798 & 6,5812 & 6,2982 & 18,9592 & 6,3197 \\
C & 7,7857 & 7,8528 & 8,1486 & 23,7871 & 7,9290 \\
D & 8,9297 & 9,5111 & 9,2373 & 27,6781 & 9,2260 \\
\hline
\end{tabular}

$\mathrm{CF}=\frac{(89,1889)^{2}}{12}=\frac{7954,6599}{12}=662,8883$

$\mathrm{Jk}$ total $=(6,0444)^{2}+(6,2014)^{2}+\ldots \ldots \ldots \ldots . .+(9,2373)^{2}-\mathrm{CF}$ $=681,6406-662,8883=18,7523$

$\mathrm{Jk}$ perlakuan $=\frac{(18,7645)^{2}+(18,9592)^{2}+\ldots \ldots \ldots+(27,6781)^{2}}{3}$

$$
-\mathrm{CF}=681,1537-662,8883=18,2654
$$

Jk Error $=\mathrm{Jk}$ total $-\mathrm{Jk}$ perlakuan

$$
=18,7523-18,2654=0,4869
$$

Tabel 3. Analisa sidik ragan (ANOVA) CRD untuk tegangan putus

\begin{tabular}{l|r|r|r|r|r|r}
\hline Sumber variasi & dk & Jk & R Jk & F hitung & F 5\% & F 1\% \\
\hline Perlakuan & 3 & 18,2654 & 6,0885 & $99,9754 *$ & 4,07 & 7,59 \\
Error & 8 & 0,4869 & 0,0609 & & & \\
Total & 11 & 18,7523 & 1,7048 & & & \\
\hline
\end{tabular}

Dari tabel 3 ternyata $\mathrm{F}$ hitung / F 5\% maupun F 1\%, sehingga dapat disimpulkan bahwa diantara perlakuan terdapat perbedaan yang sangat nyata. 
Tabel 4. Notasi dengan LSD $5 \%$ dan LSD $1 \%$ untuk uji tegangan putus

\begin{tabular}{c|c|c|c|c}
\hline Perlakuan & Total & Rata-rata & $\begin{array}{c}\text { Notasi LSD } \\
5 \%\end{array}$ & $\begin{array}{c}\text { Notasi LSD } \\
1 \%\end{array}$ \\
\hline A & 18,7645 & 6,2548 & a & a \\
B & 18,9592 & 6,3197 & a & a \\
C & 23,7871 & 7,9290 & b & b \\
D & 27,6781 & 9,2260 & & $c$ \\
\hline
\end{tabular}

Dari tabel diatas kompon D (40 bagian kompon PVC) tegang- . an putusnya paling tinggi dan berbeda nyata dengan kompon A, B, C.

Cara perhitungan statistik untuk pengujian sifat-sifat fisika lainnya sama seperti tersebut diatas.

\section{KESIMPULAN}

Dengan penambahan kompon PVC akan menaikkan tegangan putus dan kekerasan.

Hal tersebut dapat terlihat pada perhitungan statistik dengan metoda CRD, yang menunjukkan bahwa kompon D (40 bagian kompon PVC) memberikan hasil uji yang paling tinggi untuk tegangan putus $9,2260 \mathrm{~N} / \mathrm{mm}^{2}$ dan kekerasan 54.6666 Shore A.

Berdasarkan perbandingan hasil uji fisika kompon sol karet dengan variasi penambahan kompon PVC dengan SII No. 10944 Sepatu kanvas untuk umum, tersifat fisika kompon D yang memenuhi adalah tegangan putus, perpanjangan putus, kekerasan, perpanjangan tetap, bobot jenis, ketahanan retak lentur.

Sedangkan untuk ketahanan sobek dan ketahanan kikis tidak memenuhi.

\section{DAFTAR PUSTAKA}

1. Anonimous, " Manual of PVC Additive ", Ciba Geigy, Meurenberg, GMBH, 1971.

2. Anonimous, "Rubber Technology and Manufacture ", SPB Board of Consultan and Engineers.

3. Budiman, S. Ir. "Jenis-jenis karet alam dan karet sintetis", Balai Penelitian Perkebunan Bogor, 1974.

4. Harry Barron, "Modern Rubber Chemistry ", D. Van Nostrand Company Inc. 1948. New York, USA.

5. Maurice Morton, "Rubber Technology ", Reinhold Publishing Corporation Third Brinting, 1965, New York.

6. Soewarti Soeseno," Pedoman Pengujian Sifat Fisika Barang Jadi Karet ".

7. Tj. Sharp, AIRI and JA ROSS, BSc., ARIC, API. "Nitril Rubber / Polyvinyl Chlorida Blends ". BTR Industries Ltd, Leylan, 1961.

8. T. Kusnata, " Pengujian Fisika pada karet ", Balai Penelitian Perkebunan Bogor. 